and nitrogen at atmospheric pressure. Before use the electrodes were strongly heated in a vacuum to remove all occluded gases. After passing the discharge for sixty hours, the electrodes were strongly heated and, after removing a small trace of hydrogen, pure helium was obtained. This result is one of very few in which belium has been obtained without the presence of neon, and may be accepted as a final disproof of any contamination by air. Moreover, no rare gas was obtained with the uncondensed discharge in the same apparatus.

These more recent results would seem to establish the reality of the formation of helium and neon in vacuum tubes, and completely to confirm the original observations by Collie, Patterson, and Masson. As regards the origin of these gases, we believe that they arise from the disintegration of the nitrogen atom. Attention may be directed to the fact that hydrogen is always to be found in the residual gases along with the helium and neon, although the greatest possible care was taken to remove it from the electrodes before each experiment. At the same time it may be pointed out that in spite of all precautions it is impossible to secure the total absence of oxides of carbon. Whilst it seems very improbable that our last recorded observation at atmospheric pressure can be attributed to the disintegration of carbon, it may be mentioned that Bell and Bassett (Science, 56, 512, 1922) noted the presence of helium lines in the spectrum of the negative tongue of the Sperry searchlight and suggest that this gas is produced by the disintegration of the carbon atom.

E. C. C. Baly.

R. W. RidING.

Chemical Laboratories,

University of Liverpool, September 27.

\section{The Canadian School of Prehistory in France.}

ThE Canadian School of Prehistoric Research in France was started in Ottawa, Canada, in May I925, when twelve fellows of the Royal Society of Canada were elected on a committee for the object in question. The first year's work in France under the auspices of "Les Beaux-Arts de France" in Paris, Ministry of Public Instruction, Department of Historical Monuments, etc., has just closed its labours, and the School can now be stated to have been fairly well launched and started, having gathered a rather extensive and interesting lot of materials for study and distribution to various academic and scientific centres throughout the Dominion.

The site, or gisement, granted by the Beaux-Arts to Canada is situated in the Dordogne district, at Combe-Capelle, near Monferrand, up the beautiful valley of the Couze river, Commune of St. AvitSénieur. Amongst the many problems in prehistory to be solved, there occur a number at this locality, as well as in other not distant gisements, including La Micoque and other Moustierian sites of the Vèzère valley.

Combe-Capelle was expected to yield some information desired, and the result of the work of the Canadian School at this site, in June, July, and August, has revealed a certain amount of excellent material--especially at the base of the section examined-bearing upon some of those problems. No sensational discoveries were made in this virgin piece of excavation, but a large amount of workedstone implements of a very primitive sort were found in four distinct layers or beds at CombeCapelle.

Two nearly complete skeletons of a fairly large rodent (Marmota), besides isolated and fragmentary bones and teeth of bison, equus, rhinoceros (?), were added to the collections of flint or stone implements made on the spot. The work was undertaken as a careful and methodical piece of investigation under the auspices of the Beaux-Arts in order to obtain certain definite results. Very curiously and roughly shaped implements were found in all of the four layers traversed, being especially abundant in the oldest two beds. Types not hitherto much heeded, on close examination, proved to be either new or unrecorded implements made by Moustierian man as revealed in the Combe-Capelle station, exhibiting much cleverness and skill, as well as resourcefulness in the result of his industrial achievements in stone.

The type of human beings living in this very eariy stage of man's civilisation utilised even the simplest, rudest, or most common type of flint-flake, obtained by one or more well-directed blows given by his right hand or left hand, holding a percuteur or hammer, and from this flake wrought a number of fascinating shapes of instruments for his everyday use, whether it were for hunting, skinning animals, cleaning hides, building canoes, or for domestic purposes.

This ancient citizen of the Couze valley, like Moustierian man of other parts of France, of the Channel Islands, and of Great Britain, made a number of racloirs (scrapers), tranchets, blades, knives, saws, and other tools of rough, yet of intelligent workmanship. All the implements found reveal, as of to-day, two types of men: one, careful and industrious, taking an intelligent interest in his work; the other, careless perhaps and heedless of the advantage of turning out a well-made tool, satisfied with a com. paratively inferior article to meet his tastes in all likelihood. There were good, fine, and well-made implements discovered at Combe-Capelle, of materials carefully chosen, carefully wrought, which any or e, even a twentieth-century man, might be proud to be able to produce. Time, evidently, was not of very much consideration, and amongst the best, or carefully made tools, some must have taken quite a long time to make.

Careful study of the various types discovered at Combe-Capelle by members of the Canadian School in France remains to be made, and it is hoped that excellent results will be achieved, besides the procuring of specimens to illustrate the various epochs in the history of human civilisation, for which France is specially noted:

The Chellean Period (Chelles in Seine and Marne); the Acheulean (Somme valley): Moustierian (Vézère valley); Aurignacian (southern France and at CroMagnon in Les Eyzies); Magdalenian (La Madeleine, of the Vézère valley): the Azilian (Mas-d'Azil, of southern France) ; and the Tardenoisian (Tardenoisen-Fer)-all French stations marking the advancement and progress of humanity throughout the ages of man in Quaternary times, in the last chapter of the history of life on this planet. H. M. AMI.

London, September 25.

\section{Liveing's Fire-Damp Indicator.}

THE author of a note on p. 497 of NATURE of October 2, while giving credit to $\mathrm{E}$. $\mathrm{H}$. Liveing as the originator of the method of detecting and measuring fire-damp by means of an electrically heated platinum wire, wrote: "The apparatus in skilful hands would certainly measure fire-damp, but its value lay rather in its promise than in its practical utility." I desire to protest against this disparaging statement. I helped Mr. Liveing to make his original magnetoelectrical machine, for this was before the days of the Faure battery or the Clowes hydrogen lamp. While 